OPEN ACCESS

Edited by:

Joao Batista Teixeira da Rocha, Federal University of Santa Maria,

Brazil

Reviewed by:

Vilena Kasuba,

Institute for Medical Research and Occupational Health, Croatia

Gareth Jenkins,

Swansea University, United Kingdom

Hamiyet Donmez-Altuntas,

Erciyes University, Turkey

*Correspondence:

Gustavo Rafael Mazzaron

Barcelos

gustavo.barcelos@unifesp.br

${ }^{\dagger}$ These authors have contributed equally to this work

Specialty section:

This article was submitted to

Toxicogenomics,

a section of the journal

Frontiers in Genetics

Received: 05 January 2021

Accepted: 19 March 2021

Published: 20 April 2021

Citation:

Duarte NAA, Lima LE, Maraslis FI,

Kundi $M$, Nunes $E A$ and

Barcelos GRM (2021) Acute Toxicity and DNA Instability Induced by

Exposure to Low Doses of Triclosan and Phthalate DEHP, and Their

Combinations, in vitro.

Front. Genet. 12:649845.

doi: 10.3389/fgene.2021.649845

\section{Acute Toxicity and DNA Instability Induced by Exposure to Low Doses of Triclosan and Phthalate DEHP, and Their Combinations, in vitro}

\author{
Nathalia de Assis Aguilar Duarte ${ }^{1 t}$, Lindiane Eloisa de Lima ${ }^{1 t}$, Flora Troina Maraslis', \\ Michael Kundi ${ }^{2}$, Emilene Arusievicz Nunes ${ }^{1}$ and Gustavo Rafael Mazzaron Barcelos ${ }^{1 *}$ \\ ${ }^{1}$ Department of Biosciences, Institute of Health and Society, Federal University of São Paulo, Santos, Brazil, ${ }^{2}$ Institute \\ of Environmental Health, Medical University of Vienna, Vienna, Austria
}

Triclosan (TCS) is an antimicrobial agent widely used in personal care products (PCP) and the di-(2-ethyl hydroxy-phthalate) (DEHP) is a chemical compound derived from phthalic acid, used in medical devices and plastic products with polyvinyl chloride (PVCs). As result of their extensive use, TCS and DEHP have been found in the environment and previous studies demonstrated the association between their exposure and toxic effects, mostly in aquatic organisms, but there is a shortage in the literature concerning the exposure of TCS and DEHP in human cells. The aim of the present study was to assess the impact of exposure to TCS and DEHP, as well as their combinations, on biomarkers related to acute toxicity and DNA instability, in HepG2 cells, by use of cytokinesis-block micronucleus cytome (CBMNCyt) assay. For that, the cultures were exposed to TCS, DEHP and combinations at doses of $0.10,1.0$, and $10 \mu \mathrm{M}$ for the period of $4 \mathrm{~h}$ and the parameters related to DNA damage (i.e., frequencies of micronuclei (MN) and nuclear buds (NBUDs), to cell division (i.e., nuclear division index (NDI) and nuclear division cytotoxic index (NDCl) and to cell death (apoptotic and necrotic cells) were scored. Clear mutagenic effects were seen in cells treated with TCS, DEHP at doses of 1.0 and $10 \mu \mathrm{M}$, but no combined effects were observed when the cells were exposed to the combinations of TCS + DEHP. On the other hand, the combination of the toxicants significantly increased the frequencies of apoptotic and necrotic cells, as well as induced alterations of biomarkers related to cell viability (NDI and NDCI), when compared to the groups treated only with TCS or DEHP. Taken together, the results showed that TCS and DEHP are also able to induce acute toxicity and DNA damage in human cells.

Keywords: co-exposure, endocrine-disrupting compounds, HepG2 cells, micronucleus, mutagenicity

\section{INTRODUCTION}

Triclosan (TCS) is a broad-spectrum antimicrobial compound used in personal care products (PCPs) (e.g., toothpaste, mouthwashes, soaps, deodorants), household cleaning products, toys, and plastics. TCS has been found frequently in rivers, effluents from sewage and water treatment plants, as well as in soil sediments (McAvoy et al., 2002; Agüera et al., 2003; Olaniyan et al., 2016). It is 
also known that the degradation of TCS may generate compounds of higher toxicity and greater persistence, such as dioxins and chlorophenols (Pusceddu et al., 2018).

Previous in vitro and in vivo studies showed that TCS presents estrogenic, antiestrogenic, and antiandrogenic properties, which appears to be related to cell lines, tissues, and animal species (for a comprehensive review, see Ishibashi et al., 2004; Kumar et al., 2009; Jung et al., 2012; Alfhili and Lee, 2019).

One of the most important mechanisms related to TCSinduced toxicity is the capacity to cause disturbances of the redox status of cells, leading to oxidative damage in lipids, proteins, and DNA (Binelli et al., 2009; Park et al., 2016; Zhang et al., 2018). Previous in vivo studies showed that TCS is able to induce genotoxicity in several aquatic organisms, such as algae, ciliated protozoa, crustaceans and microcrustaceans, and zebra mussels (Ciniglia et al., 2005; Binelli et al., 2009; Gao et al., 2015; Silva et al., 2015; Xu et al., 2015). On the other hand, few studies were carried out aiming to assess the impact of TCS exposure on mammalian organisms, either in vitro and in vivo. For example, Li et al. (2018) showed that exposure to TCS (concentrations ranging from 5.0 to $40 \mu \mathrm{M}$ ) was able to induce cell cycle arrest and apoptosis, in HepG2 cells. In weanling rats, Riad et al. (2018) found that TCS caused testicular DNA damage, increase of malondialdehyde (MDA), and decrease of superoxide dismutase (SOD). In humans, exposure to TCS was associated with high levels of urinary 8-hydroxy-2'-deoxyguanosine (8OHdG) in children from China (Lv et al., 2016) and from Brazil (Rocha et al., 2018).

As well as TCS, the di-2-ethylhexyl phthalate (DEHP), derived from phthalic acid, is classified as endocrine-disrupting compounds (EDCs), which comprise a group of toxicants that interacts with natural hormones, interfering with their synthesis, secretion, binding, transport, and elimination, by changing their functions (Kabir et al., 2015). EDCs are widely present in products used in daily life, such as PCP, pesticides, food packaging, plastics, and flame retardants (Arambula and Patisaul, 2018). Due to its capacity to give malleability in polyvinyl chloride (PVCs), DEHP is widely used by several industries sectors, being found in medical devices, plastic packages, toys, building materials, among others (Rusyn et al., 2006; Caldwell, 2012).

DEHP is highly lipophilic and easily absorbed by the gastrointestinal tract, as well as by skin and lungs. Once absorbed, DEHP is quickly metabolized mainly in liver, resulting in several metabolites, such as the mono(2-ethylhexyl) phthalate (MEHP), which is associated with most of the toxic effects induced by DEHP exposure (Fay et al., 1999; Rusyn et al., 2006; Caldwell, 2012). Previous in vitro and in vivo studies also showed that DEHP can induce disturbances of cell homeostasis, leading to DNA instability, dysfunctions of the mitotic spindle, and cell death (Turner et al., 1974; Choi et al., 2010; Caldwell, 2012; Li et al., 2014; Rowdhwal and Chen, 2018; Silano et al., 2019).

HepG2 cells are widely used for testing the genotoxic properties of several environmental toxicants, mainly by use of micronucleus (MN) and of comet assays (for review, see Guo et al., 2020). The employment of this cell line is particularly advantageous due its ability to express several phases I and II drug metabolizing enzymes, which can catalyze the activation and detoxification of several toxicants, such as cytochrome $\mathrm{P} 450$ isoenzymes (CYP1A1, 1A2, 2B, 2C, 3A, and 2E1) and sulfotransferases (SULTs), glutathione-S-transferase (GSTs), UDP-glucuronosyltransferase (UGT), and N-acetyl-transferase (NAT); moreover, HepG2 cells also have proficient p53 gene expression, as well as functional DNA repair systems. Previous studies showed that p53-competent cells, with active expression of phases I and II drug metabolizing enzymes, as well as functional DNA repair systems may significantly reduce the rate of false positive results comprising genotoxicity assays (for review see Knasmüller et al., 2004; Mersch-Sundermann et al., 2004; Fowler et al., 2012; OECD, 2014).

As mentioned above, both chemicals are widely used on daily life and there is enough data comprising their hazard to aquatic organisms; however, it still has a lack of information of their behavior in mammalian cells. Both compounds are lipophilic, and it seems to cause damage after phase I drug metabolization system, resulting in compounds with higher toxicity (for a comprehensive review, see Caldwell, 2012; Wu et al., 2019); moreover, previous human biomonitoring studies have detected the coexposure of TCS and DEHP (or their metabolites), in urine samples of children and adults, in several regions worldwide (Casas et al., 2011; Larsson et al., 2014; Braun et al., 2017; Rocha et al., 2017, 2018; Lim, 2020; Li et al., 2021). Therefore, assessing to possible combined effect of TCS and DEHP would provide further information about molecular effects of these toxicants, as well as their interactions, in the environment and/or in organisms (Arambula and Patisaul, 2018). This study aimed to assess the impact of the exposure to TCS and DEHP, as well as their combination on biomarkers of acute toxicity and of DNA stability, in HepG2 cells.

\section{MATERIALS AND METHODS}

\section{Reagents}

TCS (triclosan; 5-chloro-2-(2,4-dichlorophenoxy) phenol; CAS 3380-34-5), DEHP (bis(2-Ethylhexyl) phthalate; CAS 117-81-7), 3,4-benzopyrene (B[a]P; CAS 50-32-8), methyl methanesulfonate (MMS; CAS 66-27-3), cytochalasin B (Cyt-B; CAS 1493096-2), dimethyl sulfoxide (DMSO; CAS 67-68-5), Giemsa (CAS 51811-82-6) and Dulbecco's Modified Eagle's Medium (DMEM, low glucose) were obtained from Sigma-Aldrich (St. Louis, MO, United States), Trypsin-EDTA (0.25\%) and antibiotic-antimycotic solution $(10,000$ units/mL of Penicillin, $10,000 \mu \mathrm{g} / \mathrm{mL}$ of Streptomycin, and $25 \mu \mathrm{g} / \mathrm{mL}$ of Amphotericin B) came from Gibco (Grand Island, NE, United States) and fetal bovine serum (FBS) was purchased from LGC Biotecnologia (Cotia, Brazil). All other chemicals, reagents, and buffers were analytical grade products from Sigma-Aldrich (St. Louis, MO, United States).

\section{Cell Culture Conditions and Treatments}

HepG2 cells were kindly provided by Prof. Dra. Lusânia M. G. Antunes from School of Pharmaceutical Sciences of Ribeirão Preto, University of São Paulo, Brazil. 
Briefly, the cells were maintained in DMEM low glucose with $10 \%$ of FBS and $1.0 \%$ of antibiotic-antimycotic, in a $\mathrm{CO}_{2}$ incubator with $5 \%$ atmosphere at $37^{\circ} \mathrm{C}$ and $96 \%$ of relative humidity. All experiments were conducted between the third and eighth cell passage.

$10^{6}$ cells were seeded in $25 \mathrm{~cm}^{2}$ cultures flasks for $24 \mathrm{~h}$ in the complete medium; after, the medium was removed, cells were washed twice with PBS ( $\mathrm{pH} 7.2$ ) and, then, cells were incubated with culture medium without FBS for the period of $4 \mathrm{~h}$, with TCS, DEHP, as well as their combinations (Figure 1); moreover, vehicle (DMSO 1.0\%) and positive controls (B[a]P $20 \mu \mathrm{M}$, and MMS $1.0 \mu \mathrm{M})$ were also included in the experiments. Concentrations of positive controls, of TCS, DEHP and their combinations were chosen based on previous MTT assays (data not shown).

\section{Cytokinesis-Block Micronucleus Cytome (CBMNCyt) Assay}

CBMNcyt assay was carried out in three independent experimental replicates following the protocol published by Fenech (2007). After exposure of the cells to TCS, DEHP, and their combinations, cells were washed twice with PBS ( $\mathrm{pH} 7.2)$ and incubated with cytochalasin $\mathrm{B}(3.0 \mu \mathrm{g} / \mathrm{mL})$ in complete medium for further $30 \mathrm{~h}$. After, cells were washed, trypsinized, and centrifuged for $5 \mathrm{~min}$ at $180 \mathrm{~g}$. Then, the pellets were resuspended in $5.0 \mathrm{~mL}$ of hypotonic solution (sodium citrate $1.0 \% ; 100 \mu \mathrm{L}$ of formaldehyde $(25 \%)$ at $4^{\circ} \mathrm{C}$ ) for $4 \mathrm{~min}$. The cells were centrifuged twice and fixed in with methanol and acetic acid $(3: 1 \mathrm{v} / \mathrm{v})$ and then, slides were prepared. Slides were stained with $5.0 \%$ Giemsa in PBS ( $\mathrm{pH} 7.2$ ) and cells were analyzed by light microscopy (Carl Zeiss, AxioLab A1, Jena, Germany) at magnification of $630 \mathrm{x}$.

In total, 3,000 binucleated cells (1,000 cells per experimental replicate) were analyzed for each experimental point. Analyses of nuclear anomalies named micronucleus (MN), nuclear buds (NBUDs), nucleoplasmatic bridges (NPBs), as well as the number of apoptotic and necrotic cells were carried out according to the scoring criteria described by Fenech (2007). Pictures of each assessed endpoint are depicted in Supplementary Figure 1. Moreover, nuclear division index (NDI) was scored in 1,500 cells (500 cells per experimental replicate) according to the formula proposed by Eastmond and Tucker (1989), as follow: $N D I=(M 1+2 . M 2+3 . M 3+4 . M 4) / N$, where "M1-M4" represent the number of cells with one, two, three, and four nuclei, respectively, and " $N$ " is the number of cells scored. Nuclear division cytotoxicity index (NDCI) was also scored in 1,500 cells (500 cells per experimental replicate) according to the formula proposed by Fenech (2000): $N D C I=(A p+N e c+M 1+2 . M 2+3 . M 3+4 . M 4) / N$, where "ap" and "nec" are the number of apoptotic and necrotic cells, "M1-M4" represent the number of cells with one, two, three, and four nuclei, respectively, and " $N$ " is the number of cells scored (both viable and non-viable ones).

\section{Statistical Analyses}

Nuclear anomalies (MN, NBUDs, and NPBs) and counts of necrotic and apoptotic cells were analyzed by Poisson regression.
Overdispersion was tested by chi-square tests. Values of NDI and NDCI were log-transformed due to their skewed distribution and analyzed by a Generalized Linear Model with Gaussian deviates. Normality of residuals was tested by Kolmogorov-Smirnov tests with Lilliefors' corrected $p$-values. Homogeneity of variances was assessed by Brown-Forsythe tests.

Values of exposed cells were compared to their controls by Wald's chi-square tests with Bonferroni corrected $p$-values. Furthermore, cells treated with the combined exposures were compared to the group that was treated with its respective single exposure (i.e., TCS vs. TCS + DEHP; and DEHP vs. TCS + DEHP; at the same doses) using the same procedure. All analyses were done by Stata 13.1 (StataCorp, College Station, TX, United States).

\section{RESULTS}

Table 1 summarizes the impact of treatments of HepG2 cells with TCS, DEHP, as well as their combinations on the parameters of cell death, cell viability, and DNA damage.

It can be seen that the lower and the intermediate doses of TCS $(0.10$ and $1.0 \mu \mathrm{M})$ were able to increase the number of cells in apoptosis when compared to the vehicle control group, while only the intermediate concentration of TCS (1.0 $\mu \mathrm{M}$ ) increased significantly the number of necrotic cells; on the other hand, significant increase of apoptosis and necrosis were seen in the cells treated with all doses of DEHP $(0.10-10 \mu \mathrm{M})$. Cotreatments of the cells with the combinations of TCS + DEHP increased significantly the percentage of both biomarkers related to cell death, with the exception of the treatment of TCS 1.0 $\mu \mathrm{M}+$ DEHP $10 \mu \mathrm{M}$. Concerning the parameters related to cell division kinetics, TCS presented higher cytostatic effects, when compared to the groups that were exposed to DEHP, measured by NDI and NDCI. Moreover, only the combination of TCS 1.0 $\mu \mathrm{M}+\mathrm{DEHP} 10 \mu \mathrm{M}$ did not induce significantly cytostatic effects, when compared to the respective vehicle control groups.

Concerning the parameters related to DNA instability, TCS, DEHP, and their combinations were able to increase the DNA damage of cells, assessed by MN and NBUDs endpoints. TCS at all concentrations $(0.10,1.0$, and $10 \mu \mathrm{M})$ was able to increase the $\mathrm{MN}$ frequencies when compared to the vehicle control group and only the lowest dose of DEHP $(0.10 \mu \mathrm{M})$ did not induce $\mathrm{MN}$ formation. When the HepG2 cells were exposed to the combination of TCS and DEHP, the treatments TCS $0.10+$ DEHP 10; TCS $1.0+$ DEHP 0.10, and TCS $10+$ DEHP 0.10 did not increase the $\mathrm{MN}$ formations, when compared to the respective vehicle control group. It is also important to mention that a significant increase of MNs was seen in cells treated with MMS and B[a]P.

Increase of NBUDs formation was seen in the groups treated alone with TCS at the intermediate and highest concentrations, i.e., at 1.0 and $10 \mu \mathrm{M}$, while higher NBUDs frequencies were seen in the cells that were treated with all doses of DEHP (0.10$10 \mu \mathrm{M})$. Concerning the cells that receive the cotreatments with to TCS + DEHP, combinations between TCS $0.10+$ DEHP 1.0, TCS $0.10+$ DEHP 10 and TCS $10+$ DEHP 0.10 did not increase 


\begin{tabular}{|c|c|c|c|c|c|c|c|c|c|c|c|c|c|c|c|c|c|c|}
\hline Treatments $(4 \mathrm{~h})$ & \multicolumn{18}{|c|}{ Experimental groups (in triplicate) } \\
\hline & $\mathbf{1}$ & 2 & 3 & 4 & 5 & 6 & 7 & 8 & 9 & 10 & 11 & 12 & 13 & 14 & 15 & 16 & 17 & 18 \\
\hline DMSO (1.0\%) & & & & & & & & & & & & & & & & & & \\
\hline MMS $(1.0 \mu \mathrm{M})$ & & & & & & & & & & & & & & & & & & \\
\hline $\mathrm{B}[\mathrm{a}] \mathrm{P}(20 \mu \mathrm{M})$ & & & & & & & & & & & & & & & & & & \\
\hline TCS $0.10 \mu \mathrm{M}$ & & & & & & & & & & & & & & & & & & \\
\hline TCS $1.0 \mu \mathrm{M}$ & & & & & & & & & & & & & & & & & & \\
\hline TCS $10 \mu \mathrm{M}$ & & & & & & & & & & & & & & & & & & \\
\hline DEHP $0.10 \mu \mathrm{M}$ & & & & & & & & & & & & & & & & & & \\
\hline DEHP $1.0 \mu \mathrm{M}$ & & & & & & & & & & & & & & & & & & \\
\hline DEHP $10 \mu \mathrm{M}$ & & & & & & & & & & & & & & & & & & \\
\hline
\end{tabular}

FIGURE 1 | Schematic overview of treatments carried out in the study.

TABLE 1 | Impact of exposure to triclosan (TCS), to phtalate DEHP, as well as their combinations on biomarkers of cell death (apoptosis and necrosis), cell viability (nuclear division index, (NDI); and nuclear division citotoxicity index (NDCl) and DNA instability (micronuclei (MN), nuclear buds (NBUDs) and nucleoplasmatic bridges (NPBs), in HepG2 cells.

\begin{tabular}{|c|c|c|c|c|c|c|c|}
\hline \multirow[t]{2}{*}{ Treatments $(\mu \mathrm{M})$} & \multicolumn{2}{|c|}{ Cell death } & \multicolumn{2}{|c|}{ Cell viability } & \multicolumn{3}{|c|}{ Mutagenic effects } \\
\hline & Apoptosis & Necrosis & NDI & NCDI & MN & NBUDs & NPBs \\
\hline DMSO $^{a}(1.0 \%)$ & $4.0 \pm 1.1$ & $5.0 \pm 1.1$ & $1.9 \pm 0.040$ & $1.8 \pm 0.030$ & $2.7 \pm 1.1$ & $1.0 \pm 1.7$ & 0 \\
\hline $\mathrm{MMS}^{b} 1.0$ & $10 \pm 2.3^{\star \star}$ & $58 \pm 3.2^{\star \star}$ & $1.7 \pm 0.11^{\star \star}$ & $1.5 \pm 0.020^{\star *}$ & $7.3 \pm 3.1^{*}$ & $1.3 \pm 1.1$ & 0 \\
\hline $\mathrm{B}[\mathrm{a}] \mathrm{P}^{c} 20$ & $4.0 \pm 1.5$ & $6.0 \pm 3.6$ & $2.0 \pm 0.13^{\star}$ & $1.8 \pm 0.030$ & $8.0 \pm 0 * \star$ & $2.7 \pm 3.1$ & 0 \\
\hline TCS 0.10 & $13 \pm 0.8^{\star \star}$ & $6.0 \pm 2.5$ & $1.7 \pm 0.040^{\star *}$ & $1.7 \pm 0.040^{\star}$ & $9.7 \pm 1.5^{\star \star}$ & $2.3 \pm 2.3$ & $0.33 \pm 0.58$ \\
\hline $\operatorname{TCS} 1.0$ & $18 \pm 6.3^{\star \star}$ & $77 \pm 7.0^{\star \star}$ & $1.7 \pm 0.010^{\star *}$ & $1.2 \pm 0.020^{\star *}$ & $11 \pm 2.5^{\star \star}$ & $11 \pm 6.8^{\star \star}$ & $1.67 \pm 0.58$ \\
\hline TCS 10 & $4.0 \pm 4.7$ & $7.0 \pm 0.82$ & $1.8 \pm 0.020$ & $1.7 \pm 0.020^{\star \star}$ & $10 \pm 5.0^{\star \star}$ & $8.7 \pm 8.1^{\star \star}$ & $0.50 \pm 0.71$ \\
\hline DEHP 0.10 & $11 \pm 2.5^{\star \star}$ & $9.0 \pm 1.1^{*}$ & $1.7 \pm 0.090^{\star \star}$ & $1.7 \pm 0.030$ & $3.3 \pm 1.5$ & $3.7 \pm 1.5^{\star}$ & 0 \\
\hline DEHP 1.0 & $30 \pm 0.50^{\star \star}$ & $16 \pm 7.2^{\star \star}$ & $1.9 \pm 0.080$ & $1.8 \pm 0.10$ & $14 \pm 1.1^{\star \star}$ & $14 \pm 10^{\star \star}$ & $1.0 \pm 1.0$ \\
\hline DEHP 10 & $13 \pm 1.2^{\star \star}$ & $33 \pm 6.2^{\star \star}$ & $1.9 \pm 0.020$ & $1.8 \pm 0.050$ & $17 \pm 3.6^{\star \star}$ & $13 \pm 5.0^{\star \star}$ & $1.7 \pm 2.0$ \\
\hline TCS 0.10 + DEHP 0.10 & $11 \pm 3.3^{\star \star}$ & $10 \pm 0.90^{*}$ & $1.6 \pm 0.10^{\star \star}$ & $1.5 \pm 0.10^{\star *}$ & $9.3 \pm 1.5^{\star \star}$ & $4.7 \pm 2.1^{*}$ & $2.3 \pm 1.5$ \\
\hline TCS 0.10 + DEHP 1.0 & $23 \pm 8.8^{\star \star}$ & $20 \pm 13^{\star \star}$ & $1.6 \pm 0.040^{\star \star}$ & $1.5 \pm 0.060^{\star \star}$ & $6.3 \pm 2.3^{\star}$ & $1.7 \pm 1.1$ & 0 \\
\hline TCS 0.10 + DEHP 10 & $30 \pm 11^{\star \star}$ & $30 \pm 24^{\star \star}$ & $1.7 \pm 0.090^{\star \star}$ & $1.6 \pm 0.16^{\star \star}$ & $1.0 \pm 0.0$ & $0.33 \pm 0.58$ & 0 \\
\hline TCS 1.0 + DEHP 0.10 & $31 \pm 23^{\star \star}$ & $28 \pm 20^{\star \star}$ & $1.7 \pm 0.050^{\star \star}$ & $1.5 \pm 0.17^{\star \star}$ & $3.3 \pm 0.58$ & $15 \pm 2.6^{\star}$ & $0.33 \pm 0.58$ \\
\hline TCS 1.0 + DEHP 1.0 & $39 \pm 20^{\star *}$ & $33 \pm 20^{\star \star}$ & $1.8 \pm 0.10^{\star}$ & $1.6 \pm 0.11^{\star \star}$ & $15 \pm 2.6^{\star \star}$ & $7.7 \pm 4.5^{\star \star}$ & $1.3 \pm 1.5$ \\
\hline TCS 1.0 + DEHP 10 & $2.0 \pm 0.90$ & $7.0 \pm 1.7$ & $1.8 \pm 0.070^{\star *}$ & $1.8 \pm 0.070$ & $16 \pm 2.0^{\star \star}$ & $12 \pm 8.0^{\star *}$ & $0.67 \pm 0.58$ \\
\hline TCS 10 + DEHP 0.10 & $9.0 \pm 0.80^{*}$ & $11 \pm 3.3^{*}$ & $1.7 \pm 0.10^{\star \star}$ & $1.7 \pm 0.090^{\star *}$ & $6.0 \pm 2.6$ & $1.3 \pm 0.58$ & $0.33 \pm 0.58$ \\
\hline TCS 10 + DEHP 1.0 & $11 \pm 7.3^{\star \star}$ & $34 \pm 3.7^{\star \star}$ & $1.8 \pm 0.070^{\star}$ & $1.7 \pm 0.13^{\star}$ & $9.3 \pm 4.9^{\star \star}$ & $4.3 \pm 3.2^{*}$ & $1.0 \pm 1.0$ \\
\hline TCS 10 + DEHP 10 & $38 \pm 9.5^{\star \star}$ & $54 \pm 1.2^{\star \star}$ & $1.7 \pm 0.10^{\star \star}$ & $1.6 \pm 0.050^{\star *}$ & $11 \pm 4.6^{\star \star}$ & $8.7 \pm 8.3^{\star \star}$ & $0.50 \pm 1.71$ \\
\hline
\end{tabular}

aNegative (solvent) control: dimethyl sulfoxide.

b Positive control: methylmethane sulfonate (no required biotransformation/activation).

${ }^{c}$ Positive control: benzo[a]pyrene (required biotransformation/activation).

${ }^{*} p<0.050 ;{ }^{* *} p<0.010$ (both in bold) compared to vehicle control group (DMSO).

significantly the formation of NBUDs. On the other hand, TCS, DEHP and their associations did not increase the frequencies of NPBs, when compared to the respective vehicle control.

Figures 2-4 depict the comparisons between the treatments with TCS + DEHP and their respective groups that receive TCS or DEHP alone, on parameters of cell death (apoptosis and necrosis), of cell viability (NDI and NDCI), and DNA damage (MNs, NBUDs, and NPBs), respectively.

There were no significant differences in the percentage of apoptosis and necrosis among the cells that receive the lowest dose of TCS, DEHP, as well as their combination, while an increasing number of apoptotic cells were seen in the groups that were treated with TCS 1.0 + DEHP 1.0; and TCS 10 + DEHP 10, when compared to the cells that were exposed only to TCS and to DEHP at 1.0 and $10 \mu \mathrm{M}$, respectively. Cells treated with DEHP at $1.0 \mu \mathrm{M}$ had lower necrotic events than the cotreatment with TCS + DEHP (both at $1.0 \mu \mathrm{M}$ ); on the other hand, treatment with TCS $1.0 \mu \mathrm{M}$ increases the percentage of necrosis, when compared to the group that receives TCS $1.0+$ DEHP $1.0 \mu \mathrm{M}$. It can be also observed a significant increase of necrotic cells in the treatment with the combination of TCS and DEHP (both at $10 \mu \mathrm{M}$ ) when compared to the groups that were exposed to the compounds alone (Figure 2).

Figure 3 illustrates the NDI and NDCI of cells treated with TCS, DEHP, and their associations. Combined effects were observed in the groups that receive the lowest doses of TCS and DEHP, i.e., cells treated with TCS + DEHP (both at $0.10 \mu \mathrm{M}$ ) showed a decrease of NDI and NDCI when compared to those that were exposed only to TCS or DEHP alone. Lower NDI and NDCI were also seen in the groups treated with TCS + DEHP 


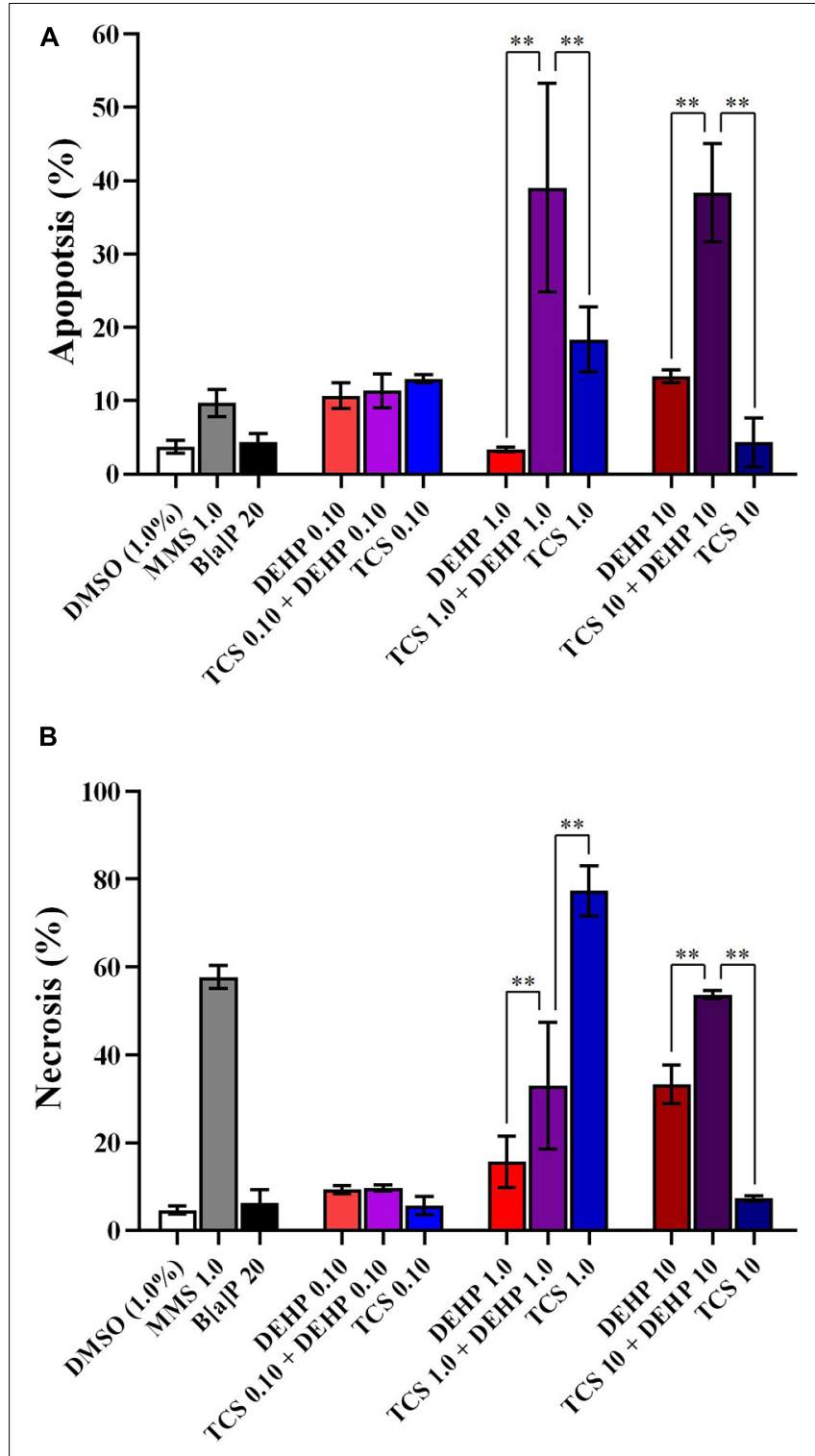

FIGURE 2 | Comparisons between the treatments with TCS + DEHP and their respective groups that receive TCS or DEHP alone, on parameters of cell death: (A) apoptosis and (B) necrosis. All doses are in $\mu$ M. ${ }^{* *} p<0.010$; Wald's chi-square tests followed by Bonferroni correction tests. (both $10 \mu \mathrm{M}$ ) when compared to the cells that receive only DEHP $10 \mu \mathrm{M}$, while no statistical difference was seen between TCS 10 $\mu \mathrm{M}$ and TCS $10+$ DEHP 10. No differences of NDI were seen among groups that receive only TCS $1.0 \mu \mathrm{M}$; DEHP $1.0 \mu \mathrm{M}$ and their association, while the lowest NDCI was observed in the cells treated with TCS $1.0 \mu \mathrm{M}$ (DEHP $1.0>$ TCS $1.0+$ DEHP $1.0>$ TCS 1.0).

Although the exposure to TCS and DEHP, as well as their combination, induces DNA instability, no combined effects were seen on the biomarkers related to DNA damage ( $\mathrm{MN}$ and NBUD formations) (Figure 4); moreover, since none of assessed

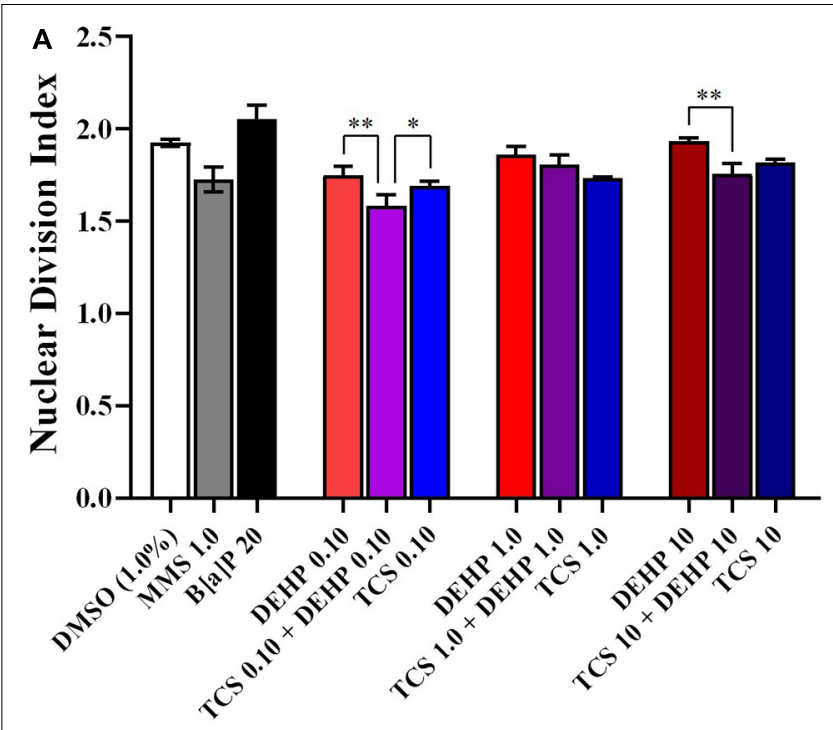

B

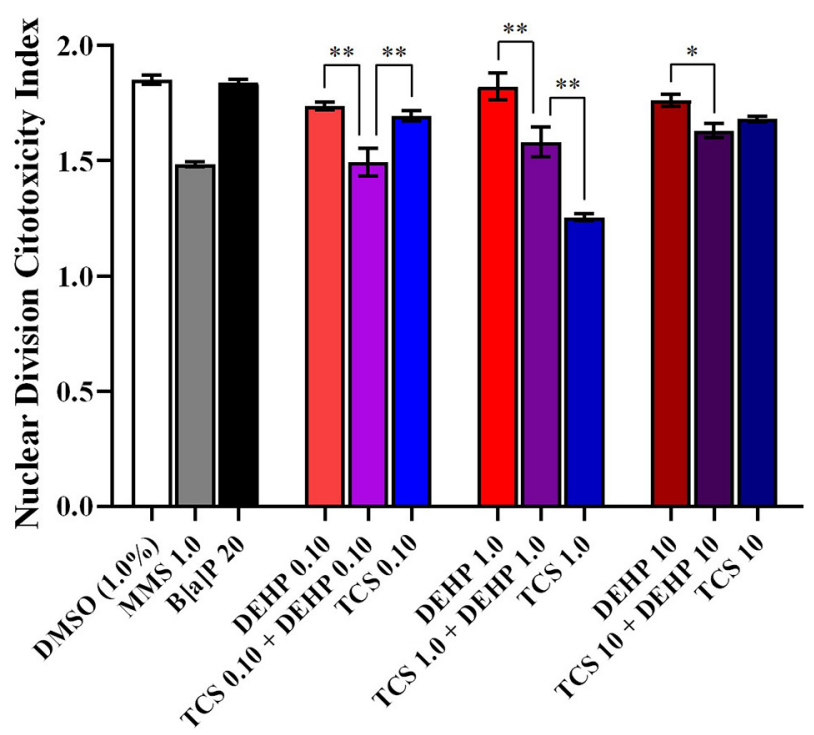

FIGURE 3 | Comparisons between the treatments with TCS + DEHP and their respective groups that receive TCS or DEHP alone, on parameters of cell viability: (A) nuclear division index (NDI) and (B) nuclear division cytotoxicity index (NDCl). All doses are in $\mu \mathrm{M} .{ }^{*} p<0.050 ;{ }^{* *} p<0.010$; Wald's chi-square tests followed by Bonferroni correction tests.

treatments induced NPBs formation, no combined effects can be seen for this endpoint (data not shown).

\section{DISCUSSION}

Previous studies showed that TCS exposure induces acute toxicity, leading to cell death. For example, Li et al. (2018) showed that TCS at concentrations of 5.0 and $10 \mu \mathrm{M}$ was able to induce DNA instability, promoting apoptosis mediated by $\mathrm{p} 53$ expression, in HepG2 cells. Li et al. (2019) observed that PC12 

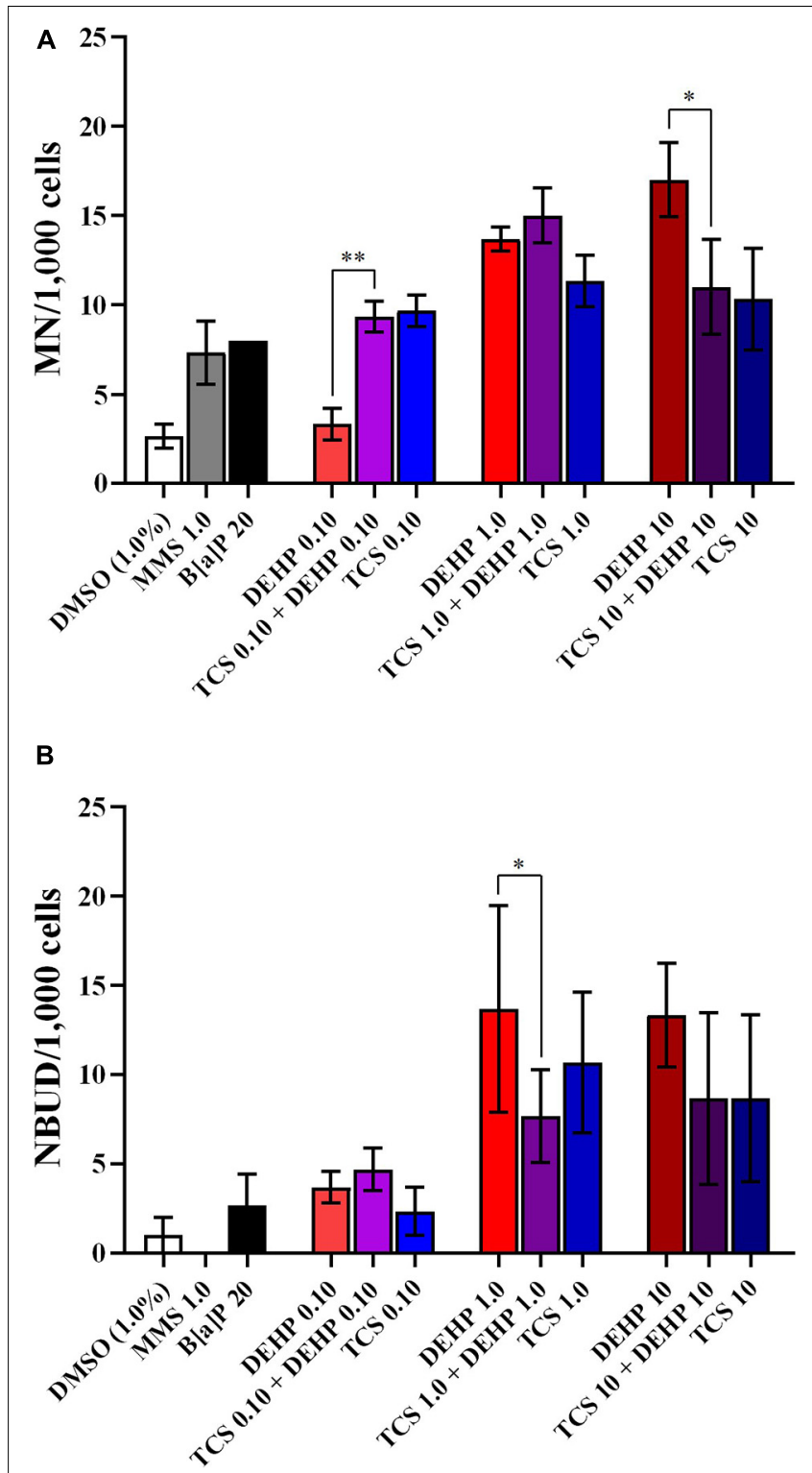

FIGURE 4 | Comparisons between the treatments with TCS + DEHP and their respective groups that receive TCS or DEHP alone, on parameters of DNA damage: (A) micronuclei (MN) formation and (B) nuclear buds (NBUDs) formation. All doses are in $\mu$ M. ${ }^{*} p<0.050 ;{ }^{* *} p<0.010$; Wald's chi-square tests followed by Bonferroni correction tests.

cells exposed to TCS at doses of 10 and $50 \mu \mathrm{M}$ for $12 \mathrm{~h}$ was able to activate the expression of $\mathrm{p} 38$ mitogen-activated protein kinase and Bax, which are related to apoptosis signaling. Moreover, Park et al. (2016) also showed that TCS-induced apoptosis in rat neural stem cells (NSCs) was mediated by Bax expression and activation of caspase 3 , at the dose of $50 \mu \mathrm{M}$. Our findings showed that the concentrations of TCS at 0.10 and $1.0 \mu \mathrm{M}$ increased the number of apoptotic cells, while the concentration of 1.0 $\mu \mathrm{M}$ enhanced the necrotic cells. Furthermore, Yueh et al. (2014) observed an increase of expression of the inflammatory cytokines named TNF $\alpha$, TNF $\beta$, and IL- 6 in the liver of male mice fed with a diet containing $0.08 \%$ of TCS for 8 months. It is well established that the expression of TNF $\alpha$, TNF $\beta$, and IL- 6 are associated with cell death signaling pathways, mainly by necrosis (D’Arcy, 2019).

Regarding to DEHP, Fang et al. (2019) assessed the impact of DEHP exposure at high dose $(512 \mu \mathrm{M}$ for $4 \mathrm{~h})$ on parameters of cell viability, in differentiated human embryonic stem cells, and observed that exposure to the compound was able to induce apoptosis by triggering the PPAR $\gamma / \mathrm{PTEN} / \mathrm{AKT}$ pathway, which is related to cell proliferation and survival. Like to TCS, cell death induced by DEHP also appears to be related to Bax expression, as well as to an increase of caspases 3 and 8, as seen previously by and Hannon et al. (2016) and Sun et al. (2018), using in vitro laboratory models. Ha et al. (2016) observed an increase of apoptotic events, in hepatocytes of Sprague-Dawley rats treated with DEHP at 250, 500, and $750 \mathrm{mg} / \mathrm{kg}$ for 30 days; according to the authors, the increase of cell death was mediated by 553 overexpression caused by DEHP exposure. Our results demonstrated that DEHP can induce apoptosis even at lower concentrations, since we observed increases in cell death at doses of 0.10 and $1.0 \mu \mathrm{M}$.

We also observed that exposure to the both EDCs was able to impact the NDI of HepG2 cells and previous studies showed that oxidative damage in DNA is related to cell cycle arrest (Droge, 2002; Murray and Carr, 2018). Reduced NDI is associated with more mononucleated cells, when compared to bi-, tri-, and polynucleated ones, giving evidence of cell cycle arrest (Fenech, 2007, 2020). Interestingly, the most pronounced effects on NDI were seen when the cells were treated with the combinations of TCS and DEHP, at all doses. This parameter is a measure of the proliferative status of viable cells fraction, if the NDI is lower than control, it can be assumed that more cells with one nucleus were scored, suggesting cytostatic effects (Fenech et al., 2011). Therefore, one hypothesis for our observations may be related to the activation of DNA repair pathways. In the cell cycle, G2/M checkpoint prevents the entry of mitosis, when DNA damage was not properly repaired. Delaying entry into mitosis allows repair mechanisms of DNA lesions before cell division, avoiding passing the damage to the new cells (Li and Zou, 2005; Gomez and Hergovich, 2016; Choi and Chung, 2020). In the NDCI, necrotic and apoptotic cells are included in the number of cells scored, since the toxic effects induced by chemical compounds may provide a large proportion of cells becoming non-viable. Therefore, an overestimated cytostatic effect can be observed in NDI if necrotic and apoptotic cells were not included in the scoring (Fenech, 2000).

In our study, clear mutagenic effects were seen in the cells exposed to TCS, DEHP and their combinations, by significant increase of MN and NBUD frequencies. An earlier study carried by Li et al. (2019) suggested exposure to TCS may be related to double strand breaks (DSBs), since the authors observed a significant increase of comet formations in HepG2 cells treated with TCS at 20 and $40 \mu \mathrm{M}$, when compared to the negative control group; in the same investigation, the authors described that DNA-dependent protein kinase (DNA-PKcs) is required for the DNA double-strand break repair through the nonhomologous end-joining (NHEJ) pathway. The formation of $\mathrm{MN}$ 
occurs during cell division when the genetic material is exposed to mutagenic compounds promoting the break of chromosomes (by clastogenic agents, which are related to acentric fragments) or loss of whole chromosomes (by aneugenic agents, which are related to disturbances of mitotic spindle formation); therefore, both (whole chromosomes or their fragments) are not incorporated into the main nucleus during the telophase and they are surrounded by a nuclear membrane, generating a MN (Fenech, 2007; Fenech et al., 2011). Earlier laboratory studies also described an association between DEHP exposure and increased DNA instability. For example, Kim et al. (2019) showed higher $\gamma \mathrm{H} 2 \mathrm{AX}$ formation in $8505 \mathrm{C}$ thyroid gland carcinoma cells treated with DEHP at concentrations ranging from 5.0 to $50 \mu \mathrm{M}$, while increased comet formations were seen in the cells treated with DEHP at doses from 5.0 to $100 \mu \mathrm{M}$. $\gamma \mathrm{H} 2 \mathrm{AX}$ is a very sensitive biomarker associated with cellular response to the induction of DNA double-strand breaks (DSBs) (Kopp and Audebert, 2019).

Our results provide further pieces of evidence that TCS and DEHP are able to induce chromosome breaks, which resulted in an increase of $\mathrm{MN}$ frequencies, especially when the cells were exposed simultaneously to both chemicals. In addition, NBUDs have a similar morphology to $\mathrm{MN}$; however, they are connected to the main nucleus by a stem of nucleoplasmatic material. Most of the NBUDs originate from interstitial or terminal acentric fragments (Fenech, 2007; Fenech et al., 2011). In this context, MNs may also arise through gene amplification through fusion bridge breaking (BFB) cycles. In the case of NBUDs, DNA is selectively located at specific locations on the periphery of the nucleus and can be eliminated through nuclear sprouting, during $S$ phase of the cell cycle; then, as consequence, extrusion of amplified DNA via nuclear sprouting may result in MN formations (Fenech and Crott, 2002; Mateuca et al., 2006; Fenech, 2020). It is also important to mention that we did not observed increase of NPBs in cells treated with TCS and DEHP. According to Bonassi and Fenech (2019), NPBs breaks generate a pair of abnormal chromosomes lacking telomeres and results in further end-fusion and gene amplification; amplified gene sequences and unresolved DNA repair complexes are removed by NBUDs formations.

Previous data report that toxicant mixtures may increase the adverse effects when compared to one only exposure (Kabir et al., 2015; Hernández et al., 2017). On the other hand, the chemical compounds may compete for similar metabolizing pathways, resulting in high biotransformation rating, which can increase or decrease the toxic effects of xenobiotics (Lin, 2006). These interactions depend on several factors, including affinity and concentration of substrates, time of exposure, and CYP450 system inhibition, for example (Deodhar et al., 2020). In this context, it is important to highlight that we assessed the exposure of TCS and DEHP in HepG2 cells, which although a tumoral cell line, they express phases 1 and 2 metabolizing enzymes (MerschSundermann et al., 2004), which may influence to toxicity related to the TCS and DEHP exposure.

Moreover, it is well known that laboratory model experiments are run under restricted controlled conditions; once in the environment, studying the interactions between these toxicants is more complex, since they can interact with more than one compound and be metabolized by bacteria, or suffering alterations by UV radiation from sunlight, for example (Rehberger et al., 2018). For this reason, studies involving mixtures of toxicants are important to emphasize the risk of these compounds to the environment and human health and it can contribute with primary data for assessing exposure biomarkers related to DNA damage and further studies with other compounds in other cells models or in in vivo models.

Taken together, our results provide further evidence concerning the mutagenic effects of TCS and DEHP in mammalian cells. Also, DNA damage induced by exposure to the both compounds may be related to delay in cell cycle and to acute toxicity. Interestingly, the most significant damages were related to exposure of lower doses of TCS, DEHP, as well as their combinations, showing that EDCs are able to induce several disturbances on cells, even at low concentrations.

\section{DATA AVAILABILITY STATEMENT}

The raw data supporting the conclusions of this article will be made available by the authors, without undue reservation.

\section{AUTHOR CONTRIBUTIONS}

GB, LL, and ND: conceptualization. EN, FM, LL, and ND: methodology, investigation. MK: statistics. EN, GB, and ND: writing original draft preparation. GB and ND: writing, review, and editing. All authors contributed to the article and approved the submitted version.

\section{FUNDING}

This study was supported by grant \#2018/02543-5 (São Paulo Research Foundation, FAPESP, Brazil), by the National Council for Scientific and Technological Development (CNPq, Brazil) and by the Coordination for the Improvement of Higher Education Personnel (CAPES, Brazil).

\section{ACKNOWLEDGMENTS}

We are grateful to the Cell Culture facilities from Federal University of São Paulo (Santos, Brazil).

\section{SUPPLEMENTARY MATERIAL}

The Supplementary Material for this article can be found online at: https://www.frontiersin.org/articles/10.3389/fgene. 2021.649845/full\#supplementary-material 


\section{REFERENCES}

Agüera, A., Fernández-Alba, A. R., Piedra, L., Mézcua, M., and Gómez, M. J. (2003). Evaluation of triclosan and biphenylol in marine sediments and urban wastewaters by pressurized liquid extraction and solid phase extraction followed by gas chromatography mass spectrometry and liquid chromatography mass spectrometry. Anal. Chim. Acta 480, 193-205. doi: 10.1016/S0003-2670(03) 00040-0

Alfhili, M. A., and Lee, M. H. (2019). Triclosan: an update on biochemical and molecular mechanisms. Oxid. Med. Cell. Longev. 2019:28. doi: 10.1155/2019/ 1607304

Arambula, S. E., and Patisaul, H. B. (2018). Endocrine disrupting chemicals and behavior. Encycl. Endocr. Dis. 1, 812-820.

Binelli, A., Cogni, D., Parolini, M., Riva, C., and Provini, A. (2009). In vivo experiments for the evaluation of genotoxic and cytotoxic effects of Triclosan in Zebra mussel hemocytes. Aquat. Toxicol. 91, 238-244. doi: 10.1016/j.aquatox. 2008.11.008

Bonassi, S., and Fenech, M. (2019). "The micronucleus assay in toxicologyin," in Issues in Toxicology, ed. D. Anderson (London: The Royal Society of Chemistry), 38-52.

Braun, J. M., Bellinger, D. C., Hauser, R., Wright, R. O., Chen, A., Calafat, A. M., et al. (2017). Prenatal phthalate, triclosan, and bisphenol a exposures and child visual-spatial abilities. Neurotox 58, 75-83. doi: 10.1016/j.neuro.2016.11.009

Caldwell, J. C. (2012). DEHP: genotoxicity and potential carcinogenic mechanisms-a review. Mutat. Res. - Rev. Mutat. Res. 751, 82-157. doi: 10.1016/j.mrrev.2012.03.001

Casas, L., Fernández, M. F., Llop, S., Guxens, M., Ballester, F., Olea, N., et al. (2011). Urinary concentrations of phthalates and phenols in a population of Spanish pregnant women and children. Environ. Int. 37:5. doi: 10.1016/j.envint.2011.02. 012

Choi, J. E., and Chung, W. (2020). Functional interplay between the oxidative stress response and DNA damage checkpoint signaling for genome maintenance in aerobic organisms. Arch. Pharm. Res. 38:5. doi: 10.1007/s12275-020-9520-x

Choi, S., Park, S. Y., Jeong, J., Cho, E., Phark, S., Lee, M., et al. (2010). Identification of toxicological biomarkers of di(2-ethylhexyl) phthalate in proteins secreted by HepG2 cells using proteomic analysis. Proteomics 10, 1831-1846. doi: 10.1002/ pmic. 200900674

Ciniglia, C., Cascone, C., Lo Giudice, R., Pinto, G., and Pollio, A. (2005) Application of methods for assessing the geno- and cytotoxicity of Triclosan to C. ehrenbergii. J. Hazard. Mater. 122, 227-232. doi: 10.1016/j.jhazmat.2005. 03.002

D'Arcy, M. S. D. (2019). Cell death: a review of the major forms of apoptosis, necrosis and autophagy. Cell Biol. Int. 43, 582-592. doi: 10.1002/cbin.11137

Deodhar, M., Rihani, S. B., Al, Arwood, M. J., Darakjian, L., Dow, P., et al. (2020). Mechanisms of CYP450 inhibition: understanding drug-drug interactions due to mechanism-based inhibition in clinical practice. Pharmaceutics $12,1-18$.

Droge, W. (2002). Free radicals in the physiological control of cell. Physiol. Rew. 82, 47-95. doi: 10.1152/physrev.00018.2001

Eastmond, D. A., and Tucker, J. D. (1989). Identification of aneuploidy-inducing agents using cytokinesis-blocked human lymphocytes and an antikinetochore antibody. Environ. Mol. Mutagen. 13, 34-43. doi: 10.1002/em.2850130104

Fang, H., Fang, W., Cao, H., Luo, S., Cong, J., Liu, S., et al. (2019). Di-(2ethylhexyl)-phthalate induces apoptosis via the PPAR $\gamma / \mathrm{PTEN} / \mathrm{AKT}$ pathway in differentiated human embryonic stem cells. Food Chem. Toxicol. 131, 1-8.

Fay, M., Donohue, J. M., and De Rosa, C. (1999). ATSDR evaluation of health effects of chemicals. VI. Di(2-ethylhexyl)phthalate. Toxicol. Ind. Health 15, 651-732. doi: 10.1191/074823399678847023

Fenech, M. (2000). The in vitro micronucleus technique. Mutat. Res. 455, 81-95. doi: 10.1016/s0027-5107(00)00065-8

Fenech, M. (2007). Cytokinesis-block micronucleus cytome assay. Nat. Protoc. 2, 1084-1104. doi: 10.1038/nprot.2007.77

Fenech, M. (2020). Cytokinesis-Block micronucleus cytome assay evolution into a more comprehensive method to measure chromosomal instability. Genes 11:1203. doi: 10.3390/genes11101203

Fenech, M., and Crott, J. W. (2002). Micronuclei, nucleoplasmic bridges and nuclear buds induced in folic acid deficient human lymphocytes - Evidence for breakage-fusion-bridge cycles in the cytokinesis-block micronucleus assay. Mutat. Res. 504, 131-136. doi: 10.1016/s0027-5107(02)00086-6
Fenech, M., Kirsch-Volders, M., Natarajan, A. T., Surralles, J., Crott, J. W., Parry, J., et al. (2011). Molecular mechanisms of micronucleus, nucleoplasmic bridge and nuclear bud formation in mammalian and human cells. Mutagenesis 26, 125-132. doi: 10.1093/mutage/geq052

Fowler, P., Smith, R., Smith, K., Young, J., Jeffrey, L., Kirkland, D., et al. (2012). Reduction of misleading ("false") positive results in mammalian cell genotoxicity assays. II. Importance of accurate toxicity measurement. Mutat. Res. - Genet. Toxicol. Environ. Mutagen. 747, 104-117. doi: 10.1016/j.mrgentox. 2012.04.013

Gao, L., Yuan, T., Cheng, P., Bai, Q., Zhou, C., Ao, J., et al. (2015). Effects of triclosan and triclocarban on the growth inhibition, cell viability, genotoxicity and multixenobiotic resistance responses of Tetrahymena thermophila. Chemosphere 139, 434-440. doi: 10.1016/j.chemosphere.2015.07.059

Gomez, V., and Hergovich, A. (2016). Cell-Cycle Control and DNA-Damage Signaling in Mammals, Genome Stability. Amsterdam: Elsevier Inc.

Guo, X., Seo, J. E., Li, X., and Mei, N. (2020). Genetic toxicity assessment using liver cell models: past, present, and future. J. Toxicol. Environ. Health B. Crit. Rev. 23, 27-50. doi: 10.1080/10937404.2019.1692744

Ha, M., Wei, L., Guan, X., Li, L., and Liu, C. (2016). P53-dependent apoptosis contributes to di-(2-ethylhexyl) phthalate-induced hepatotoxicity. Environ. Pollut. 208, 416-425. doi: 10.1016/j.envpol.2015.10.009

Hannon, P. R., Niermann, S., and Flaws, J. A. (2016). Acute exposure to Di(2Ethylhexyl) phthalate in adulthood causes adverse reproductive outcomes later in life and accelerates reproductive aging in female mice. Toxicol. Sci. 150, 97-108. doi: 10.1093/toxsci/kfv317

Hernández, A. F., Gil, F., and Lacasaña, M. (2017). Toxicological interactions of pesticide mixtures: an update. Arch. Toxicol. 91, 3211-3223. doi: 10.1007/ s00204-017-2043-5

Ishibashi, H., Matsumura, N., Hirano, M., Matsuoka, M., Shiratsuchi, H., Ishibashi, Y., et al. (2004). Effects of triclosan on the early life stages and reproduction of medaka Oryzias latipes and induction of hepatic vitellogenin. Aquat. Toxicol. 67, 167-179. doi: 10.1016/j.aquatox.2003.12.005

Jung, E. M., An, B. S., Choi, K. C., and Jeung, E. B. (2012). Potential estrogenic activity of triclosan in the uterus of immature rats and rat pituitary GH3 cells. Toxicol. Lett. 208, 142-148. doi: 10.1016/j.toxlet.2011. 10.017

Kabir, E. R., Rahman, M. S., and Rahman, I. (2015). A review on endocrine disruptors and their possible impacts on human health. Environ. Toxicol. Pharmacol. 40, 241-258. doi: 10.1016/j.etap.2015.06.009

Kim, S., Park, G., Jo, Y., Seong, J., Taek, K., Jee, S., et al. (2019). Di-2ethylhexylphthalate promotes thyroid cell proliferation and DNA damage through activating thyrotropin-receptor-mediated pathways in vitro and in vivo. Food Chem. Toxicol. 124, 265-272. doi: 10.1016/j.fct.2018. 12.010

Knasmüller, S., Mersch-sundermann, V., Kevekordes, S., and Darroudi, F. (2004). Use of human-derived liver cell lines for the detection of environmental and dietary genotoxicants. Curr. State Knowledge 198, 315-328. doi: 10.1016/j.tox. 2004.02.008

Kopp, B., and Audebert, L. K. M. (2019). Validation of the $\gamma \mathrm{H} 2 \mathrm{AX}$ biomarker for genotoxicity assessment: a review. Arch. Toxicol. 93, 2103-2114. doi: 10.1007/ s00204-019-02511-9

Kumar, V., Chakraborty, A., Kural, M. R., and Roy, P. (2009). Alteration of testicular steroidogenesis and histopathology of reproductive system in male rats treated with triclosan. Reprod. Toxicol. 27, 177-185. doi: 10.1016/j. reprotox.2008.12.002

Larsson, K., Ljung Björklund, K., Palm, B., Wennberg, M., Kaj, L., Lindh, C. H., et al. (2014). Exposure determinants of phthalates, parabens, bisphenol A and triclosan in Swedish mothers and their children. Environ. Int. 73, 323-333. doi: 10.1016/j.envint.2014.08.014

Li, H., An, J., Zhong, Y., He, H., Wang, L., Yang, Y., et al. (2018). Comparison of hepatotoxicity and mechanisms induced by triclosan (TCS) and methyltriclosan (MTCS) in human liver hepatocellular HepG2 cells. Toxicol. Res. (Camb) 8, 38-45. doi: 10.1039/c8tx00199e

Li, L., and Zou, L. (2005). Sensing, signaling, and responding to DNA damage: organization of the checkpoint pathways in mammalian cells. J. Cell. Biochem. 94, 298-306. doi: 10.1002/jcb.20355

Li, S. J., Chen, P., Peres, T. V., Villahoz, B. F., Zhang, Z., Miah, M. R., et al. (2019). Triclosan induces PC12 cells injury is accompanied by inhibition of 
AKT/mTOR and activation of p38 pathway. Neurotoxicology 74, 221-229. doi: 10.1016/j.neuro.2019.07.008

Li, X., Fang, E. F., Scheibye-Knudsen, M., Cui, H., Qiu, L., Li, J., et al. (2014). Di(2-ethylhexyl) phthalate inhibits DNA replication leading to hyperPARylation, SIRT1 attenuation, and mitochondrial dysfunction in the testis. Sci. Rep. 4:6434.

Li, X., Zhong, Y., He, W., Huang, S., Li, Q., Guo, C., et al. (2021). Co-exposure and health risks of parabens, bisphenols, triclosan, phthalate metabolites and hydroxyl polycyclic aromatic hydrocarbons based on simultaneous detection in urine samples from guangzhou, south China. Environ. Pollut. 272:115990. doi: 10.1016/j.envpol.2020.115990

Lim, S. (2020). The associations between personal care products use, and urinary concentrations of phthalates, parabens, and triclosan in various age groups: the korean national environmental health survey cycle 3. 2015-2017. Sci. Total Environ. 742:140640. doi: 10.1016/j.scitotenv.2020.140640

Lin, J. H. (2006). Expert review CYP induction-mediated drug interactions: in vitro assessment and clinical implications. Pharm Res. 23, 1089-1116. doi: 10.1007/ s11095-006-0277-7

Lv, Y., Rui, C., Dai, Y., Pang, Q., Li, Y., Fan, R., et al. (2016). Exposure of children to BPA through dust and the association of urinary BPA and triclosan with oxidative stress in Guangzhou, China. Environ. Sci. Process. Impacts 18, 1492-1499. doi: 10.1039/c6em00472e

Mateuca, R., Lombaert, N., Aka, P. V., and Decordier, I. (2006). Chromosomal changes: induction, detection methods and applicability in human biomonitoring detection methods, and applicability in human biomonitoring. Biochimie 88, 1515-1531. doi: 10.1016/j.biochi.2006.07.004

McAvoy, D. C., Schatowitz, B., Jacob, M., Hauk, A., and Eckhoff, W. S. (2002). Measurement of triclosan in wastewater treatment systems. Environ. Toxicol. Chem. 21:1323. doi: 10.1002/etc.5620210701

Mersch-Sundermann, V., Knasmüller, S., Wu, X. J., Darroudi, F., and Kassie, F. (2004). Use of a human-derived liver cell line for the detection of cytoprotective, antigenotoxic and cogenotoxic agents. Toxicology 198, 329-340. doi: 10.1016/j. tox.2004.02.009

Murray, J. M., and Carr, A. M. (2018). Integrating DNA damage repair with the cell cycle. Curr. Opin. Cell Biol. 52, 120-125. doi: 10.1016/j.ceb.2018.03.006

OECD (2014). Test No. 487: in Vitro Mammalian Cell Micronucleus Test. Test No. 487 Vitr. Mamm. Cell Micronucleus Test. Paris: OECD, doi: 10.1787/ 9789264224438-en

Olaniyan, L. W. B., Mkwetshana, N., and Okoh, A. I. (2016). Triclosan in water, implications for human and environmental health. Springerplus 5:1639. doi: 10.1186/s40064-016-3287-x

Park, B. K., Gonzales, E. L. T., Yang, S. M., Bang, M., Choi, C. S., and Shin, C. Y. (2016). Effects of triclosan on neural stem cell viability and survival. Biomol. Ther. 24, 99-107. doi: 10.4062/biomolther.2015.164

Pusceddu, F. H., Choueri, R. B., Pereira, C. D. S., Cortez, F. S., Santos, D. R. A., Moreno, B. B., et al. (2018). Environmental risk assessment of triclosan and ibuprofen in marine sediments using individual and sub-individual endpoints. Environ. Pollut. 232, 274-283. doi: 10.1016/j.envpol.2017.09.046

Rehberger, K., Kropf, C., and Segner, H. (2018). In vitro or not in vitro: a short journey through a long history. Environ. Sci. Eur. 30:23. doi: 10.1186/s12302018-0151-3

Riad, M. A., Abd-Rabo, M. M., Abd, El Aziz, S. A., El Behairy, A. M., and Badawy, M. M. (2018). Reproductive toxic impact of subchronic treatment with combined butylparaben and triclosan in weanling male rats. J. Biochem. Mol. Toxicol. 32:e22037. doi: 10.1002/jbt.22037

Rocha, B. A., Asimakopoulos, A. G., Barbosa, F., and Kannan, K. (2017). Urinary concentrations of 25 phthalate metabolites in Brazilian children and their association with oxidative DNA damage. Sci. Total Environ. 586, 152-162. doi: 10.1016/j.scitotenv.2017.01.193

Rocha, B. A., Asimakopoulos, A. G., Honda, M., da Costa, N. L., Barbosa, R. M., Barbosa, F., et al. (2018). Advanced data mining approaches in the assessment of urinary concentrations of bisphenols, chlorophenols, parabens and benzophenones in Brazilian children and their association to DNA damage. Environ. Int. 116, 269-277. doi: 10.1016/j.envint.2018.04.023

Rowdhwal, S. S. S., and Chen, J. (2018). Toxic effects of Di-2-ethylhexyl phthalate: an overview. Biomed Res. Int. 2018:1750368. doi: 10.1155/2018/1750368

Rusyn, I., Peters, J., and Cunningham, M. (2006). Modes of action and speciesspecific effects of di-(2-ethylhexyl)phthalate in the liver. Crit. Rev. Toxicol. 36, 459-479. doi: 10.1080/10408440600779065

Silano, V., Barat Baviera, J. M., Bolognesi, C., Chesson, A., Cocconcelli, P. S., Crebelli, R., et al. (2019). Update of the risk assessment of di-butylphthalate (DBP), butyl-benzyl-phthalate (BBP), bis(2-ethylhexyl)phthalate (DEHP), diisononylphthalate (DINP) and di-isodecylphthalate (DIDP) for use in food contact materials. EFSA J. 17:5838. doi: 10.2903/j.efsa.2019.5838

Silva, A. R. R., Cardoso, D. N., Cruz, A., Lourenço, J., Mendo, S., Soares, A. M. V. M., et al. (2015). Ecotoxicity and genotoxicity of a binary combination of triclosan and carbendazim to Daphnia magna. Ecotoxicol. Environ. Saf. 115, 279-290. doi: 10.1016/j.ecoenv.2015 02.022

Sun, Y., Shen, J., Zeng, L., Yang, D., Shao, S., Wang, J., et al. (2018). Role of autophagy in di-2-ethylhexyl phthalate (DEHP)-induced apoptosis in mouse Leydig cells. Environ. Pollut. 243, 563-572. doi: 10.1016/j.envpol.2018. 08.089

Turner, J. H., Petricciani, J. C., Crouch, M. L., and Wenger, S. (1974). An evaluation of the effects of diethylhexyl phthalate (DEHP) on mitotically capable cells in blood packs. Transfusion 14, 560-566. doi: 10.1111/j.1537-2995.1974.tb04577.x

Wu, M., Xu, L., Teng, C., Xiao, X., Hu, W., Chen, J., et al. (2019). Involvement of oxidative stress in di-2-ethylhexyl phthalate (DEHP)-induced apoptosis of mouse NE-4C neural stem cells. Neurotoxicology 70, 41-47. doi: 10.1016/j. neuro.2018.10.013

Xu, X., Lu, Y., Zhang, D., Wang, Y., and Zhou, X. (2015). Toxic assessment of triclosan and triclocarban on Artemia salina. Bull. Environ. Contam. Toxicol. 95, 728-733. doi: 10.1007/s00128-015-1641-2

Yueh, M. F., Taniguchib, K., Chena, S., Evansc, R. M., Hammockd, B. D., Karinb, M., et al. (2014). The commonly used antimicrobial additive triclosan is a liver tumor promoter. Proc. Natl. Acad. Sci. U S A. 111, 17200-17205. doi: 10.1073/pnas.1419119111

Zhang, P., Yang, M., Zeng, L., and Liu, C. (2018). P38/TRHrDependent regulation of TPO in thyroid cells contributes to the hypothyroidism of triclosan-treated rats. Cell. Physiol. Biochem. 45, $1303-$ 1315. doi: $10.1159 / 000487558$

Conflict of Interest: The authors declare that the research was conducted in the absence of any commercial or financial relationships that could be construed as a potential conflict of interest.

Copyright (c) 2021 Duarte, Lima, Maraslis, Kundi, Nunes and Barcelos. This is an open-access article distributed under the terms of the Creative Commons Attribution License (CC BY). The use, distribution or reproduction in other forums is permitted, provided the original author(s) and the copyright owner(s) are credited and that the original publication in this journal is cited, in accordance with accepted academic practice. No use, distribution or reproduction is permitted which does not comply with these terms. 